RESEARCHARTICLE

\title{
Performative metaphors influencing the art practice of women artists from different global locations
}

\author{
Nish Belford* \\ Faculty of Education, Monash University, Melbourne, Australia
}

\begin{abstract}
In this paper, 'performative metaphors' is used as a framework to foreground questions of women artist's positioning and 'visibility' in the global art world. Four women artists who practice in different countries, considered core, semi-peripheral and peripheral global locations, shared their views and subjectivities in relation to their nationality, cultural, and religious identities conjointly, with other ideologies and philosophies have influenced their art and practice. The researcher, having a migrant artist identity, positions herself as a critical ethnographer and takes a reflexive stance in examining the participant's responses. The intersection of literature, from feminist theories and other socio-cultural lenses, extend the discussion on issues of agency, activism, identity, voice, and visibility afforded to the women artists' as examined from their perspectives. However, this paper also stipulates the lack of visibility and attention given to other women artists mainly from global peripheral countries and those having a migrant artist identity. The conclusion draws on the possibilities for bridging collective identities with an ongoing conversation triggered by the four women artists while extending this discourse to a broader audience.
\end{abstract}

\section{Keywords}

Open Access

Citation: Belford, N. Performative metaphors influencing the art practice of women artists from different global locations. Gender and Women's Studies. 2019; 2(2):4.

Received: September 26, 2018 Accepted: February 15, 2019 Published: March 6, 2019

Copyright: @ $\odot 2019$ Belford N. This is an open access article distributed under the terms of the Creative Commons Attribution License, which permits unrestricted use, distribution, and reproduction in any medium, provided the original author and source are credited.

Corresponding author: Nish Belford, Faculty of Education, Monash University, Melbourne, Australia

E-mail:nish.belford@monash.edu
Feminist theories, geographical positioning, and visibility of women artists in the global art world, performative metaphors, subjectivities

\section{Introduction}

There are several factors, which can influence an artist's view and their artistic representations (Jones, Runco, Dorman, \& Freeland, 1997). Wolff (1981) in her study on the social production of art from history and literature argues that contemporary art is also a collective product influenced by both different kinds of direct or indirect social and political factors and the constraints of contemporary artist's experiences. Griselda Pollock's (2013) article, 'how much gender influence the art world' poses questions about the real impact of gender on output and perception in the art world. In response to an exhibition, entitled 'The Nature of Women' in the Mayor Gallery in London in 2013, displaying six female abstract artist's artworks, Pollock (2013) queries the title of this exhibition. She believed that the title of the exhibition was justified by women's close link to nature and the abstraction in their artworks defined from flawed and stereotypical thinking. Such misconceptions, Pollock (2013) argues, once again segregates women in not considering other variables such as geometry, mathematics, spirituality, or philosophy in engendering abstraction in the women artist's artworks in that exhibition. Feminist inquiries have demised the positioning, 'visibility' of female artists fostered from the legacies of Victorian ideas, based only on a specific feminine, and hence, a secondary view (Pollock, 2013). Writers such as Virginia Woolf have raged and questioned the censored and silenced contribution of gender and women's freedom in creating art. The visibility of women artists has been an issue discussed and prioritised since the 1940s by art dealers such as Peggy Guggenheim (Pollock, 2013). 
Current discourses still draw on oblique and stereotypical thinking resulting in the exclusion of many contemporary women artists in relation to the selective tradition of modernism and gender (Deepwell, 1998; Gray, 2009; Harris, 2002; Iskin, 2017). Similarly, the visibility and the challenges of women artists, practicing from countries considered within global peripheral locations and those having a migrant artist identity, is thinly discussed through literature (Bal \& Hernández-Navarro, 2011; Dekel, 2016; Elkins, Valiavicharska, \& Kim, 2010; Kramarae \& Spender, 2004; Petersen, 2017; Tamboukou, 2010b). For instance, from a non-gendered perspective, there is a further need to research the loss of geographical frontiers within modern international art, with more debates on the globe-trotting of artists in the global art world (Petersen, 2017). Likewise, the hybrid aesthetics of migrant artists' artworks and the subjectivities they encounter, towards their art practice under different social and cultural conditions, need further scrutiny. This paper examines the perspectives of four women artists while considering how their geographic location, socio-cultural conditions, values, and beliefs influence their art practice and views. Coming from different countries considered within core, semi-peripheral, and peripheral global locations (the United States and Australia, South Africa, and Saudi Arabia), the different profiles of the women artists (one having a migrant artist identity and others have lived and practiced in different countries) provide discursive insights on their art practice and views.

'Performative metaphors' (Fernandez, 1972, 1977) and the notion of 'performative subjectivity' (Butler, 1990) is used as a framework, to foreground questions of visibility and positioning of the participants, while exploring their views and subjectivities about their art practice. The performative understanding of 'metaphors' articulates some of the unquestioned value systems and issues around the socio-cultural values, religious beliefs, geographic location, and other philosophies and ideologies that build meaning, purpose, and influences the participant's views and artworks. A review of literature underlines; the 'visibility' and 'voice' of women artists in the global art world and also presents a brief theoretical underpinning of the terms 'performative metaphors' and 'performative subjectivity.'

The researcher is positioned as a critical ethnographer (Madison, 2011; Simon \& Dippo, 1986; Thomas, 1993). As a women artist with a migrant identity, the researcher takes a reflexive stance in analysing, interpreting, and in reciprocally engaging with women artists' responses. The women artists' selective views (both as visual/textual data) (O'Neill, 2001; Pink, 2013) includes both their responses and artworks, which contribute to supporting each artist's perspectives. Reflecting on feminist theories and other socio-cultural lenses (Ahmed, 2003; Berman, 2017; Ellsworth, 1992; Kennelly, 2014; McNay, 2016; Mikaelsson, 2016) the discussion examines the affordance of activism, agency, voice, and visibility of the women artists, as examined from their responses. The conclusion draws on the possibilities for collective identities as other women artists will resonate having similar experiences. The paper also considers the visibility of women artists practicing from global peripheral countries and those having a migrant artist identity.

\section{Literature review}

\section{Visibility of women artists}

Feminist inquiry has focused on how history produces and reproduces marginalisation and exclusion of women artists, based on the selective tradition of modernism and gender in the twentieth century (Deepwell, 1998; Gray, 2009; Harris, 2002). The primary questions of such inquiry related to normative modern art canons in assessing the quality of women artists' work and the relationship of their work to contemporary concepts of femininity. The question of value and judgement in using modern art canons as frameworks for interpretation and analysis has created unequal barriers of validation and categorisation of artists as 'major' or 'minor' and such ideologies often demarcate whether women artists' are worthy subjects for research (Deepwell, 1998).

Such ideologies have also contributed to an under-representation, lack of ackowledgement and visibility for women artists practicing from countries considered within the global peripheries (Gray, 2009) of the so-called Western world and to some extent, to those having a migrant artist identity (Petersen, 2017). A differentiated cultural affiliation rather, than geographical designation (Iskin, 2017) contributes to such disparities and stereotypical understanding. The visibility and access of women artists practicing from global peripheral countries are only sparingly discussed, within feminist art history and scholarly literature, 
although they are known to participate in global events such as international art biennales and often have online media coverage, websites, and personal blogs.

Similarly, writing about women artists remains "a highly specialised, even esoteric, occupation or irrelevance to the main agenda" (Deepwell, 1998, p. 2). Women artists who write about their work are rarely published as a guide to teaching their ideas and practices (Deepwell, 1998; Gray, 2009). Equally, writing stories about women artists (Tamboukou, 2010a, 2010b) is challenging, owing to the different genres involved where, for instance, artists' biographies are mostly consider edclichés. In general, the valuing of artworks and experiences is often regarded as a vehicle for constituting the female self through art (Herrero, 2012). Limited studies draw on women artists' stories and the purpose of their art (Armstrong \& de Zegher, 2006; Bradley, 2015; Fortnum, 1998; Gotsi, 2005; Grosenick \& Becker, 2001; Heartney, Posner, Princenthal, \& Scott, 2014; Khakbaz, 2015). Other studies refer to the disempowering aspects of women artists (Deepwell, 1998; Gray, 2009; Harris, 2002). Even within those studies, there is little emphasis on the global positioning and socio-cultural implications informing women artists' perspectives and their art practice. This paper examines the perceived subjectivities of four women artists in exploring different issues that influence their views and how these factors contribute meaning and purpose to their work.

\section{Voice of the women artists}

The concept of voice, as suggested by Ellsworth (1992), is not used to give subordinate others a voice in telling their stories, nor it is used for self-defining feminist voices to construct collective meanings. As Berman (2017) suggests finding a voice through art practice and artworks (visual voice) can emphasise the power and potential of collective voices. The polyvocality (Mirza, 2006) in this study lies in there searcher's ability to communicate, interpret, and acknowledge the reciprocity (Butler-Kisber, 2010) within the women artists' views and experiences. This approach also supports an understanding of "the relevancy of multi subjective, interpretive and dialogic and polyphonic ethnographic texts" (Clifford, 1988; as cited in Mackinlay, 2007, p.93). Similarly, Lather (2008) claims that voice, authenticity, and empathy can be grounds for research, which supports the critical ethnographic and reflexive stance in this study, yet in proposing another way to move forward in valuing the notions of voice, agency, and visibility of the women artists. The study draws on the sociological and cultural aspects surrounding the art practice of women artists, however, it also considers 'voice' to exceed any presumed race, gender, class, or cultural locations (Subreenduth \& Jeong-eun, 2010).

\section{Performative metaphors}

"Metaphor is one of the few devices we have for leaping beyond the essential privacy of the experiential process" (Fernandez, 1972, p.41). It is often mobilised wherever and whenever people struggle to express the inexpressible" (Riggins, 1994, p. 27). Ortony (1975) defines the function of metaphors first, "as a compact way of conveying a great deal of information and secondly as a means to "convey the inexpressible or the more dynamic and continuous aspects of experience" (Riggins, 1994, p. 27). Fernandez's $(1977,1986)$ work reminds us of the figurative expression of applying metaphors in understanding human behaviour not merely through explicit linguistic use of figures of speech. 'Metaphors,' in his work, provide reference and conception for group members to experience social solidarity and other religious ideals as performed through ritual actions and cults. He focuses on the unities of experience and the metaphors and other tropes predicated upon group members in giving them an actionable identity.

In this study, 'performative metaphors' function as a metaphorical idea (Fernandez 1972, 1977) in organising and enacting the 'metaphors,' which influence four women artists' experience, their views, and subjectivities. 'Performative metaphors,' also foreground questions of visibility and positioning of women artists' agency and voice, and how their shared views open an ongoing conversation to abroader audience with other avenues in bridging collective identities (Melucci, 1995).

\section{Performative subjectivity}

Butler proposes the notion of performativity in developing an analysis of gender as performance (Zembylas, 2005). Butler (1990) sees gender not just as an act, but as materially 'performative' (Diamond, 1996, p.4) and argues that "we cannot even assume a stable subjectivity that goes about performing various gender roles; rather, it is the very act of 
performing gender that constitutes who we are" (Felluga, 2015, p.115). Butler (1996) proposes an understanding of "subjectivity as the product of social discourse" and "agency in terms of the process of resignification: the subject who is produced in and through discourse can act by articulating words in contexts that invest them with new meaning" (Magnus, 2006, p.82-83).

Butler's (1996) theory of 'performativity' and the deconstruction of gender helps to understand meanings through acts, practices, or ways of constructing and performing identities. Similarly, the notion of 'performative subjectivity'(Butler, 1990) has demonstrated the emancipatory power and the induced social transformations it brings (Magnus, 2006). In this study, Butler's notion of 'performativity' serves two important functions: first, it enables to problematise the notion of 'performative metaphors' as part of the subjectivities of women artists' art practice and discursive views. Secondly, it suggests a different conceptualisation of agency in highlighting the role of 'performative metaphors', in the positioning and visibility of women artists in the global art world, and the possibilities for bridging collective identities.

\section{Methodological approach}

\section{Critical ethnography and researcher's positionality}

As a qualitative research method, critical ethnography is undertaken on the presumption that the issues identified, as the target of the research, warrant attention and need attention and recognition (Wolcott, 1999).Critical ethnographers use other lenses to explore further the 'what might be' factors and issues in a study (Thomas, 1993) and take a more engaging position in raising " their voice to speak to an audience on behalf of their subjects" (Wolcott, 1999 , p. 183). In this study, the use of critical ethnography involves a value-laden orientation (Creswell, 2007) in examining the factors that influence women artists' art practices and views. As a critical ethnographer, the researcher intrinsically connects to the women artists' views and issues bearing on her personal experiences with a migrant artist identity (Simon \& Dippo, 1986). As a polyvocal inquiry, this paper offers reciprocal reflexivity (Butler-Kisber, 2010) with both the emic views of the women artists and the etic perspective of the researcher. From an outsider's status, the researcher adopts a reflexive stance in interpreting the meanings emerging through the women artists' responses (Cohen, 2018; Wolcott, 2008). This approach also informs the researcher's démarche in contextualising, representing, interpreting, and discussing the different variables explored in this paper. It establishes the reflexive dialogue the researcher engages in, speaking out on behalf of the women artists, while simultaneously engaging them in the research process. Reflexive researchers tend to bring their own values, experiences, knowledge, and backgrounds to the research situation (Bettez, 2015). In acknowledging her positionality in the study, the researcher is conscious of her authority in examining her intentions and possible effects relative to her representation and interpretation of the women artists responses (Madison, 2011).

\section{Data generation}

\section{Selection of participants}

A convenience sampling reached out to a group of four women artists of culturally and ethnically diverse origins and nationalities, as they were from different countries - Saudi Arabia (peripheral country), South Africa (semi-peripheral country), and Australia and the United States (core countries) (Chase-Dunn, Kawano, \& Brewer, 2000). Each of the women artists brings a different insight to art practice and their artistic representations. Their responses are individually, inspiring but collectively, rich in addressing different issues and commonalities from their unique positioning and views. This study examines only four women artists' perspectives; however, a critical ethnographic lens uncovers the various influences informing their work while catching ethnographic data that contributes to extending knowledge in this field. Beyond this, the study also exposes data informing the ideology and critique of women artists within different profiles while practicing from different geographic locations. The views of the four women artists also inform how global positioning, visibility, access, and opportunity are an integral part of art practice (Cohen, 2018; Creswell, 2012; Thomas, 1993).

\section{Ethical considerations}

The women artists were invited for voluntary participation in the study. A lay summary (the 
plain language statement) outlined the ethical considerations, risks, and benefits to the participants. The purpose of the study and the researcher's interest and positioning were communicated. The women artists consented for their identification using their real names in the study and granted permission for using images of their artworks in any publications arising from this study. The online questionnaire facilitated access to participants from different countries as they could respond at their convenience and time (Gillham, 2008; Johnson \& Christensen, 2010). The open-ended nature of the questionnaires allowed flexibility to narrate experiences and to address any sensitive areas related to their needs and views (see attached sample of questions in the appendix). Women artists were given autonomy to choose the artworks for inclusions in their responses. This approach attended to ethical issues in using and gaining access to the participants' artworks and views.

\section{Profile of the women artists}

\section{Name: Dana Awartani}

\section{Country of birth: SaudiArabia}

\section{Country of residence: Jeddah, SaudiArabia}

Artistic profile: Dana is a Palestinian Saudi artist born and raised in Jeddah, Saudi Arabia. As a contemporary artist, she has refined her skills in Islamic art forms. Her work is inspired by traditional art and techniques of craft making, particularly the relationship between geometry and nature and how universal truths can be translated into art using geometric principles. Her work is firmly rooted in this traditional approach and practices in seeking to visualise a sacred language through symbolic and multilayered aesthetic. She has completed national and international outreach projects throughout schools and communities to further her appreciation of the traditional arts.

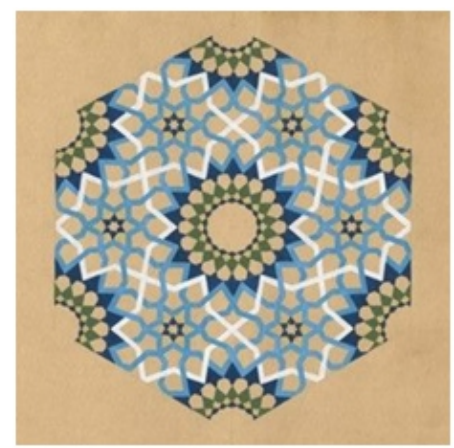

Figure 1. ZHART AL LOTOUS- Lotus flower 2 shell gold \& natural pigments on prepared paper $(15 \times 17.5 \mathrm{~cm}) 2013$

\section{Name: Liza Gobler}

\section{Country of birth: South Africa}

\section{Country of residence: Cape Town, South Africa}

Artistic profile: Through her artworks, she explores the tangible qualities of materials and the connections between people, artworks, and the world around us. She often employs craft techniques in the construction of her artworks. Her installations create dialogues with the spaces in which they are displayed. The viewer is encouraged to travel with her into an imaginary world where fact and fiction becomes one. In this world, everything is in flux, and anything is possible. The objects, images, and installations are constructed through collaboration, interaction, and exchange.

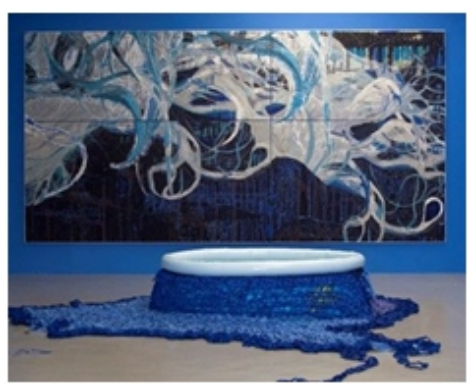

Figure 2. White Termite (installation at Brundyn + Gallery: Cape town) Mixed media Installation 2012 


\section{Name: Alicia Marvan}

Country of birth: Mexico

\section{Country of residence: New York, United States}

Artistic profile: Alicia is an artist, designer, and curator dedicated to contemporary and experimental practices. Her interdisciplinary approach to art/life has led her to an ongoing investigation of a variety of media that explores space, form, movement, time and thought, often in relation to the human body. Current projects bridge performance, sculpture, and architecture, delving into human physicality and identity as they relate to place and history.

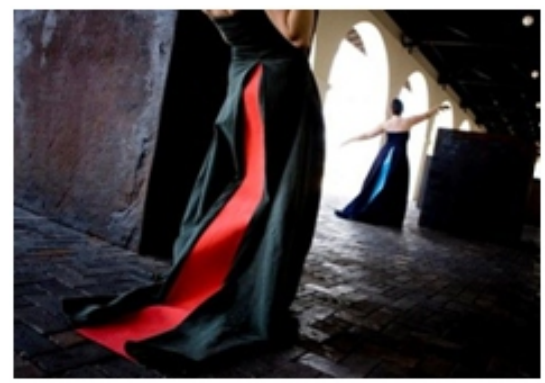

Figure 3. Zero-crossing (2007)

The word is the specified performance amongst Richard Serra's sculptures. Commissioned by the Museum of Contemporary Art San Diego. In mathematics, a "zero-crossing is a point where a graph crosses a zero value axis. Inspired by the term and the site's constant flux of people from USA and Mexico, two dancers slowly collide, representing the two cultures' interaction at the border. Direction: Alicia Marván. Performance: Alicia Marván and Jessica Radulowich, Duration: 30 minutes

Name: Tracy Dods

\section{Country of birth: Australia}

\section{Country of residence: Blue Mountains, New South Wales, Australia}

Artistic profile: Tracy works through sketches of people on the beach and in the city and by taking hundreds of photos. As she paints, the story of the subject unfolds . . .often relating to what books or articles she is reading at the time... . and the title of the painting comes to mind. She works with acrylic paint and a lot of water to achieve a dripping, spraying and washing it with technique. The yin and yang (Daoism) is a very important part of the overall piece, the yin of the water and the strength (yang) of the figure. Often the horizon is slightly higher on one side of the figure ... to give an unsettled feeling of movement. The figure is often in blue-black, and she sometimes uses ink to get the shiny feel of the suits ... the capes and overcoats she likes to pour the paint and mimic a Rorschach test, and this gives a feeling of spontaneity and movement. All her figures merge in some way with the environment, and all have a slight white aura.

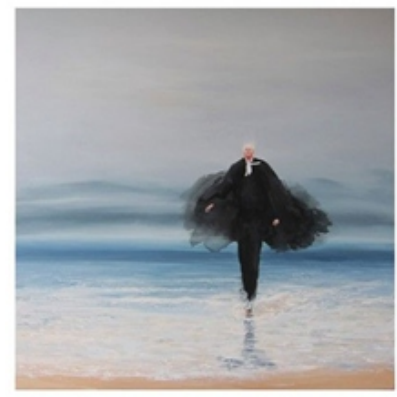

Figure 4. "Avarice and Greed,"Acrylic on canvas $122 \times 122 \mathrm{~cm}$

This work is from a series of works inspired by ethical and moral values and dogmatic theory. The symbolic figure of the Criminal Court, one of our more trusted and respected figures in society and one often not leaving up to expectations. I am interested in defining our belief in a generally moral society, despite this disingenuous behaviour. . . and that perhaps that belief is called Faith

\section{Visual and textual data}

In critical ethnography, fieldwork and interviews (Madison, 2011) are main sources for data 
generation. There are also different types of ethnographic data, which include questionnaires and visual data (Le Compte \& Schensul, 2010). O'Neill (2001) suggests the representation of the visual/artistic form of data through ethnographic work to facilitate a richer understanding of the complexities of lived experiences. In this study, the women artist's artworks and their views illuminate the broader social structures and processes influencing their art practice and subjectivities. The visual and textual data offer distinct means of access to "forms of social knowledge that strengthens, challenge, and contradict" the way they understand their social world (Stanczak, 2007, p. 20). Ethnographic research "intertwines visual images and metaphors" in conveying experiences from art making, and the processes involved in analysing them becomes part of the ethnographic knowledge" (Pink 2001, p. 17). The combination of the visual/textual data facilitated an understanding and interpretation of the women artist's representations and their subjectivities around art practice while reaching out to a wider audience beyond academic communities (O'Neill, 2001).

\section{Data analysis and interpretation}

Through a process of coding and sorting the responses, from the women artists (Saldana, 2011), emerging themes and categories were identified (Creswell, 2007; Wolcott, 1999). The categories examined included: (1) Nationality and the socio-cultural implications influencing an artistic practice (2) Subjectivities within the women's art practices influenced by their ideologies, philosophies, and identity; and (3) Geographic location and the influences on art practice. From these categories and other hunches from the women artist's responses, themes were put together in constructing the vignettes for the discussion. From higher-level coding (Carspecken, 1996; 2013) links were made to the potential tensions between what the women artists did and said and what they ought to do from their experiences (Creswell, 2007). Performative metaphors' and subjectivities, influencing their art practice, were used as an overarching lens to draw upon further interpretation from their responses (Trent \& Cho, 2014). The focus on the specific analysis of themes was deliberate although it did not overlook the complexities within the participant's responses. Thereon, the emphasis on the vignettes in the discussion were: (1) Boundaries of nationalism, cultural and religious identities -Activism and agency from an art practice; (2) Subjectivities from differing ideologies and philosophies Influencing art practices; and (3) Geographic positioning influencing the visibility of women artists.

Positioned as a critical ethnographer, the researcher adopted a reflexive stance (Phillips, Kristiansen, Vehviläinen, \& Gunnarsson, 2013) along with a dialogical approach allow ingreciprocity (Butler-Kisber, 2010) in extending the choice between "conceptual alternatives" and making of value-laden meaning (Thomas \& O' Maolchatha, 1989, p. 147). A dialogic approach was used to "harness the transformative power" of the social, cultural, and geographical differences with undertones of reflexivity in enhancing "the discourse of dialogue, participation, and empowerment" (Phillips et al., 2013, p.8)

\section{Women artist's responses - Artworks and Perspectives}

\section{Nationality and the socio-cultural implications influencing an artistic practice}

Several factors can influence the development of artistic interests and abilities. In this study, a synchronic account of the four women artists' current activities, as independent subjects, is examined from identified categories and the ways different factors influenced their views and art practice. In response to a question asking them to define how their ethnicity, gender, religion, and cultural identity influences their ideas and what they represent through their artworks, the women artists conveyed strong responses to personal beliefs, religion, migration, and mobility, cultural identity, and patriotism among other issues to inform their intentions and artistic representations.

Dana Awartani from Saudi Arabia mentioned that she was brought up in a female dominant matriarchal family, yet her experiences living for a long time in the United Kingdom have also contributed to her emancipatory views in situating herself in Saudi Arabia, the host country that is now her current place of residence. The multicultural ethnic background and her lived experiences in the United Kingdom have contributed to her ability to use a more tolerant and inclusive lens to identify herself, without any self-labelling within a specific cultural/ethnic group identity and belonging.

\section{Dana Awartani states:}

My work is influenced mostly by my religion, not my gender or ethnicity. This is due to the 
fact I have a very multicultural background, I have a mixture of Palestinian, Syrian and Saudi in me and I find it very difficult to identify with one culture. Regarding gender I have been raised in a very female dominant family and living for so long in the UK my gender has neverbeen an issue, drawback or problem forme personally.

From her artwork, the influence of religion is a statement of her faith, and she pays her respects to the same in not using human forms but rather adopting numbers, geometry, floral patterns and colours to translate her ideas and ideologies in artistic expression (see figure 5). She focuses on the concept of the six days of creation in the Islamic tradition. As she explains:

I have made an embodiment of this concept through the use of geometry and illumination. The six panels depict the creation process of an illuminated manuscript commonly found in Qurans, and I have used to mirror the story of creation. These manuscripts were made to represent the heavens and the earth through the use of symbolism in aesthetics. Since the use of the human form is not favoured in Islamic art, they have adopted the use of numbers, geometry, colour, and floral motifs to translate ideas that are more abstract. Another reason these art forms were used was to mirror Gods creations on earth as a form of worship as it states in the Quran: to know me to know my creations.

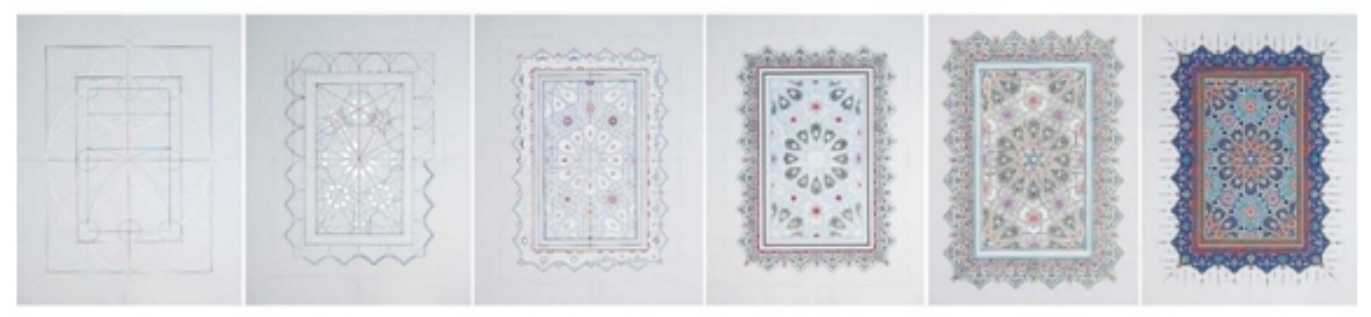

Figure 5. HE WHO CREATED THE HEAVENS AND THE EARTH IN SIX DAYS Natural pigments and shell gold on paper, $82 \times 390 \mathrm{~cm}, 2013$

Alicia Marvan found her Mexican cultural heritage to have a strong influence on her values and artistic representations. She mentioned that Mexicans by nature are centred on the sensory with colours, textures, and flavours and these are part of social interaction and cherished as a part of their daily existence. Thus, she positions herself in society as per the required cultural norms and ideals from her cultural heritage and she is conscious of her gender roles. However, she also points out that she is inclined to manifest and challenge some of the heteronormative assumptions in some of her artworks, which liberates herby expressing her feminine entitlement and experiences as a liberal Mexican:

Being from Mexico has marked me with a very defined way to relate to the world. As a culture, we are very centred in the sensorial: we cherish colour, textures, flavours, physical interaction, and that shows in our art, in my work too. Also, as a Mexican woman, I have always been very aware of my role in society, the expectations and ideals society puts on women. In several of my works, I have questioned and challenged those assumptions. In others, I celebrate the "raw" feminine, the freedom I experience as a liberal Mexican.

In most of her works, Alicia Marvan conveys a powerful message of the ambivalence and hybridity, as she feels torn between her Mexican cultural heritage and identity, while her acculturation within a new space in New York also creates ambivalences in ways she negotiates her identity. In her work, 'On the edge' (see figure 6) she exhibited and performed this ambivalence in expressing cultural identity and nationalism as lived and experienced with the symbolism of two flags that represent her dual nationalities. 


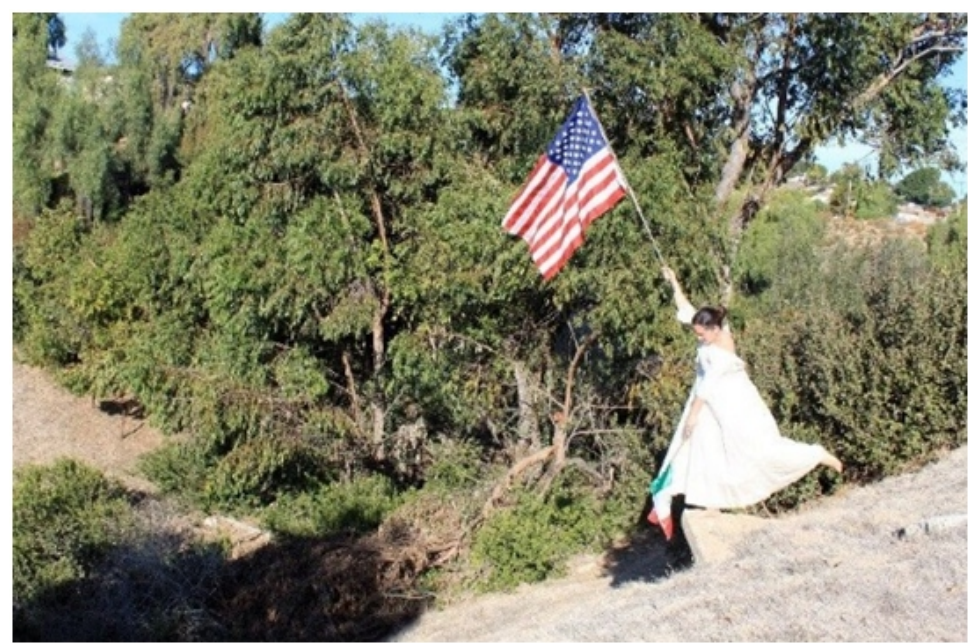

Figure 6. On the Edge (2013)

A photographic study is documenting a performative exploration of nationality.

Photographs by Andrea Marván.

Alicia Marvan shared her about this work:

In 2013, I obtained my USA citizenship, after 17 years as a legal resident of the country. It was a great achievement, yet I kept feeling sorrow and guilt, almost like I had betrayed Mexico. In the photographs, I am depicted on the edge of a canyon, balancing two flags/nationalities. The USA flag is larger and I hold it up high, representing the opportunities and achievements I have had in this country. Mexico's flag is smaller and is almost slipping from my hand, dangerously dangling over the canyon, representing my struggle with the country's current socio-political and economic reality.

In her work, 'Zero-crossings' (see figure 4) Alicia Marvan further demonstrates her perception of the cultural alienation and breach of Mexican cultural heritage and belonging claiming:

"I migrated to San Diego, California from central México and stayed there for nine years. All this time, even though I quickly acculturated, I never quite felt like I could relate to the culture. . . it seemed like I was communicating with people just on the surface, and from far away- the piece represents this cultural breach."

As a migrant Alicia Marvan mentions her intentions both in her artworks and views demonstrating her efforts towards acculturation, yet it also suggests her nostalgia and anxiety in breaching her Mexican cultural heritage. As Guibernau and Rex (2010) suggest in many cases nationalism adopts an ethnic character depending on the ideologies attached to it and can manifest in many forms, and in Alicia's experiences her feeling of belonging, nostalgia, and cultural breach.

Liza Gobler who practices in South Africa mentioned that: "we are a product of our context and artists, especially, are exceptional sponges and mostly what we produce is a result of action or reaction to our environment." Her works draw on the context, environment, and the people she works with. Hersite-specific work " $21^{1 \text { st }}$ Century: Family Portrait (Stellenbosch) (see figure 7) shows her clear démarche in making connections of the personal to the relational and the global. She defines this approach more as a social experiment involving performance and celebration with people and friends within her daily life. The dialogue between one and the other and the interaction with the maker and the viewer is fluid. As a form of activism, this work deploys strong messages of her positionality within the realms and metaphors of performativity. 

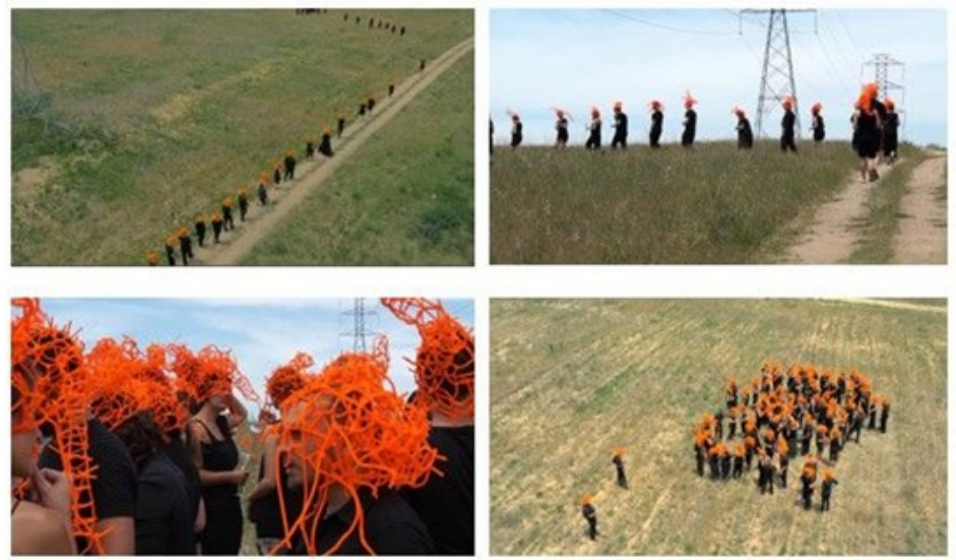

Figure $7.21^{\text {st }}$ Century: Family Portrait (Stellenbosch) Celebration/ film, 2014 Liza Gobler also adds:

My fortieth birthday was on Sunday 7 December 2014. To commemorate four decades on this planet, I created an event in which my friends and co-workers could become active participants - call it a video cameo, "family portrait" for the $21^{\text {st }}$ Century...or perhaps a type of social experiment. The aim was to create an event where everyone that forms part of my daily life could interact, sip bubbly and be physically present in the same space for a set period (midday). Participants wearing pipe cleaner headpieces walked into an empty field, where they took position around a zinc bath filled with bubbly and then connected there headpieces to other participants while a saxophonist (a modern-day pied piper) played haunting overtones. These "thinking caps" are visual analogies for the exchange of ideas amongst peers, connections between people, social networks and the World Wide Web. It followed on from the White Termite exhibition demonstrating the relevance of eachin relation to the group and also the relationship between the group and their context. And in the end how humans are only a speck on the blue planet.

In response to any influences of her ethnicity, culture, or gender in her artworks, Tracy Dods did not find such factors to directly inform her ideas and intentions in her artworks. Tracy Dodsmentions: "Not at all when I paint ... except maybe I worry about Australia and where it is heading politically and environmentally ... because I'm an Aussie ...."Her preoccupations encompass more her sense of cultural nationalism and patriotism being an Australian.

Subjectivities within the women art practices influenced by their ideologies, philosophies, and identity

Dana Awartani finds her art rooted in Islamic art traditions and emphasises the influence of her beliefs in numerology, Islamic and Sufi philosophy, geometry, sacred numbers, poetry, and symbolism as part of the design inspiration within her work and research. These influences resonate with religious norms and beliefs in Saudi Arabia. Her open-minded, philosophical beliefs are not common teaching in the Saudi Arabian culture, which is avery conservative society as regards freedom of speech, gender issues, and women's rights. Her multi-layered identity informs her emancipatory philosophies and values as she has lived in the United Kingdom. Her views, however, do not translate into purposeful forms of activism or agency as her work is grounded in her fascination with Islamic art and her religious beliefs. She thinks that her multiple layered identities are represented "in a very discreet manner" and "I never intend to do or I am aware it is present in my work." As she explains:

I am inspired a lot by Sufi philosophy and a much more versatile approach to religion which is not commonly taught in Saudi Arabia, and I was exposed to it during living in the West. My progress drawings are inspired by the idea of "Tawhid," which is the Islamic teaching of the Oneness of God. All of my drawings begin with a circle and finish with a geometric design no matter how complicated or simple the design is they finish within the circle. I do not see geometry just as a mathematical practice but also as a reflection of the laws of the universe and a way of understating our universe.

In contrast, Alicia Marvan iteratively questions her identity and sense of belonging. The hybridity emanating from a multi-layered identity, her sense of being in between two cultures 
preoccupies her thoughts as she observes, "It is a constant question: Who am I? What constitutes my identity? How am I marked by these two cultures I inhabit?" Her ideologies and philosophy are influenced by her knowledge of the art discipline of modern aesthetics and postmodern theory and her early schooling within Montessorian principles. Herspontaneity and rigour give her the freedom to express herself through more minimalist, creative and interdisciplinary practices where she also draws on postmodern concepts. She says:

I went to Montessori schooling, and as an artist, I was trained in line with Modern aesthetics and postmodern theory. Montessori: the way I develop my work, following my instincts and a rigorous, independent, and open-minded intellectual inquiry. Modernism in the way that I use an "economy" of elements in each artwork so that it becomes amplified and focused. Postmodern theory in that I incorporate many aspects of the creative, many approaches, and disciplines into an interdisciplinary practice.

Liza Gobler connects the inner and outer landscapes she represents through the performative stances in her work. "I am interested in the connection between inner and outer landscape: what is physically there versus what is interpreted (experienced) the imagination /subconscious - My work combines physical elements such as space and tangible materials, with fantasy/subconscious. "She is more interested in the connections between the physically present and the imagined - as she states:"the membrane between real and imagined is construction in itself. The outcomes are experiential rather than conceptual."

Tracy Dods mentions her preoccupations with the Australian political and economic rhetoric. She outlines Christian dogmatic theory, the myth of Sisyphus, language, body language, social interactions, writers, and humour as part of what she conveys through her work. She describes these messages and meanings as:

Language and the titles I give my work are very important. Yes, it's funny and witty . . . But. . . I get so frustrated and angry at political/corporate jargon/financial "speak." I have paintings titled as "Leverage," "Shaping the post-crisis world," "going forward," "think tank," "the stalking horse," "empire building" and this all relates back to semantics and not saying what you really mean. I think of myself as an observer. . . If I take away all the noise that surrounds the figure and incongruously place the idea in a serene, uncluttered space its motivations and intent become distilled, obvious, humorous and sometimes sad. I could just as easily place my figures in a void or a blank background . . but the sea and all it symbolizes for me and perhaps all Australians is paramount . . . the sea. . the great confessor, therapist, the fun and the frivolity and that little bit of fear of the unknown. And of course, it's representation of mother earth and climate change.

The symbolic figure. . . the everyday man is representative of these matters, which are part of her work. Her artwork entitled 'Counsel' (see figure 8) shows her ideas behind this work and she adds in her description of this work: "struck by the beauty of a group of men in suits, all uniformly dressed wheeling like a flock of birds yet all striving for individuality." Her artworks underline humour and wit from the depiction of the political, financial, and corporate world.

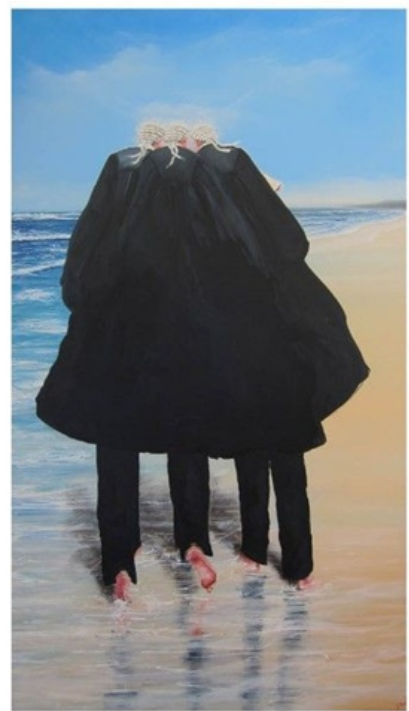

Figure 8. Counsel Acrylic on canvas 183x107, 2013 


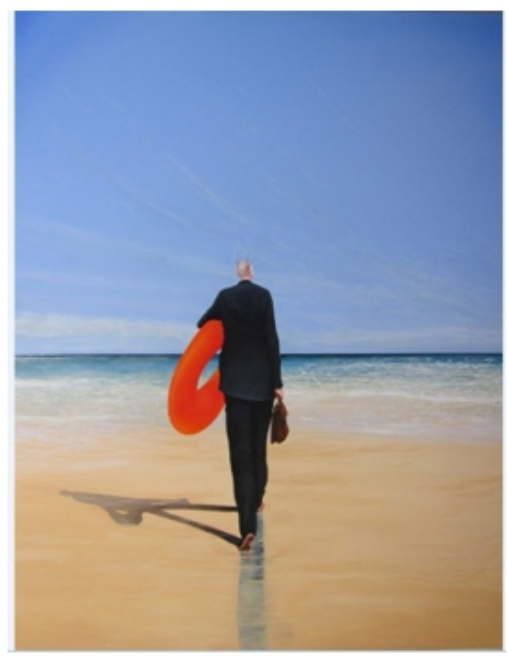

Figure 9. Leverage Acrylic on canvas 138X107, 2013

\section{Geographic location and the influences on an art practice}

An artist's geographical positioning has a significant impact on their engagement with an art practice within the global artistic community. Artworks can relate to the social and cultural context of the artist. Dana Awartani feels that living in Saudi Arabia has provided her opportunities to excel as one of the few leading Saudi women artists. She feels pursuing her artistic career in Saudi Arabia to empower her as an artist with little inhibitions for possibilities of interaction with the outer art world. She mentions traveling and making outer connections as giving her exposure to the outer world of art and states:

Being in Saudi Arabia right now I am extremely lucky because within the last few years the art scene is really flourishing and there are a lot of new galleries, collectors, patrons that really support the local talent. It's important also to state that there are not a lot of artists from Saudi so this definitely works to my advantage, whereas if I did stay in London it would be a lot more difficult and take me much longer to get to where I am today. On the downside though Saudi does not have any museums, art centres, art shops, etc.... which doesn't help you become inspired, so traveling is a must.

Liza Gobler defines her opportunities to earn a living as an artist in South Africa as challenging and different to what a Eurocentric context offers. The past political history of South Africa and the isolation of the country affects the work and exposure of artists to the outer world. However, she considers this a blessing as this situation has protected the authenticity of South African art. However, she believes that commercial galleries, individual patrons, and buyers pressure the demand for decorative pieces or murals to dictate the art market. Her views clarify this:

In South Africa most art opportunities are driven by commercial galleries and individual patrons - this is a very different model to the European one of Museums and Foundations. Also, there are more private buyers with bigger walls - painting is popular; also more decorative pieces. We are geographically very isolated, and because of our political history, we have also been cut off from the rest of the world for a long time. This isolation had two consequences: On the one hand it held us back, but on the other hand, because of limited exposure to trends in the rest of the world, the SA art scene also maintained quite a unique flavour that is currently working to the advantage of younger artists.

Alicia Marvan draws on her move from Mexico to New York as empowering her artistic career with more openings and opportunities to advance in her artistic practice. Although her cultural identity and acculturative experiences from migration strongly influence her artistic intentions and representations, she does find the geographical location a draw back for artists to perform and express their ideas. She believes that there are always many opportunities for transnational art and experiences. She mentions:

Our location, environment, and context always influence who we are and the opportunities available to us. But I believe this is in no way an impediment to expression or success. If the circumstances are not allowing us to achieve what we desire, we 
always have many other options and places to go, to pursue our dreams, and become who we aspire to be.

Tracy Dods considers her remote location in the Blue Mountains as an excellent opportunity to interact with other people belonging to a community of artists. She believes that "being removed from the city gives you the ability to see its inhabitants remotely and clearly. Also, the Blue Mountains is awash with artists, writers, and thinking types; it is inspiring to talk to like minded and sophistic types."Tracy Dods further mentions, that her work" is focussed on Australia's political, social and economic climate." She defines her family, childhood background and her upbringing more as inspiration to become an artist:

My childhood was idyllic, growing up in a hippy/aboriginal community in North Queensland, with a political/social activist and writer for a mother and a Zen Buddhist styled artist for a dad. With no T.V and only our imaginations to entertain. Our close-knit community was full of thinkers, artists, musicians, and people who had dropped out of society. There was no "normal" and certainly no bankers.

\section{Discussion}

\section{Performative metaphors influencing the women artists' art practice \\ Boundaries of nationalism, cultural and religious identities - Activism and agency from an art practice}

In the study, the boundaries of nationality, in particular, cultural and religious identities provide a better understanding of how such factors inform the four women artists' art practice and views. Dana Awartani in her artworks brings an understanding of religion more in regards to the underpinnings of theological roots informing her artistic representations. Confined to geometric forms, floral patterns, numbers, colours, and Arabic texts her artworks provide depth, commitment, and an embodiment with an immediacy of her Islamic faith and religion. However, her artworks hardly represent Islamist feminist views of other women artists and feminist movements within the Middle Eastern regions (Khakbaz, 2015). She believes that a matriarchal upbringing, her living experiences in the United Kingdom and the familial support have supported and nurtured her art practice in Saudi Arabia. Her approach and views turn more to aneutral and inclusive lens onto gender and although the value-ladenconcept of patriarchy is much present in the Saudi Arabian society (Mikaelsson, 2016) she seems to circumvent issues around gender disparity and male dominance issues with are rampant in her country (Al-Dosari, 2016). Religious beliefs and cultural expressions thus dominate her artworks in imparting meaning, purpose, and voice to her art practice.

Alicia Marvan draws on her multi-layered identities from home and host country migrant experiences. She queries the ambivalences around her nationality and patriotism as she represents and voices her ideas in her artworks. Alicia Marvan celebrates her art practice with an adjudicative agenda - she draws upon her transnational identity and perspectives inclining towards "feminist theories of agency as resistance" (McNay, 2016, p. 39).In doing so, she tries to resolve the perceived conflicts around gendered and transnational identities and subjectivities, yet from a more subtle and inclusive way in voicing her emancipatory views and actions as she practices and lives in the United States. Her work shows subversions in negotiating her cultural identities and nationality with the symbolism in her artworks and performances. The "deep-felt sense of responsibility, inflected with powerful emotions" (Kennelly, 2014, p. 246) drives her activism which informs her choices and commitment within a feminine entitlement.

As she questions the subjectivities associated with migration, mobility, and her identities Alicia also refers to the complex relations of gender and mobility (Creswell, 2012). As other migrant artists, she has an investment in cultural values from the homeland, which informs her ideologies and perceived conflicts in representing identities and agency through artistic expression (Author, 2013; Dekel, 2016; Petersen, 2017). Migrant subjects have allegiances to home, nationality, cultural beliefs, social values, and such practices often shape the attitudes and how the host culture view and understand them (Adey, 2017). Ahmed (2003) asserts that the materialities of migration can be thought together with practices of 'homing'. In other words, migrants rely on an experience of home and homing in affording them the possibilities for reclaiming and processing of uprooted habits, histories, and memories. Alicia Marvan also perceives her artistic practice as a means to express, represent, reclaim, and reprocess her 
identities as explored by other migrant artists (Belford , 2013; Dekel, 2016; Petersen, 2017) and she strongly refers to her cultural history and patriotism to the home country. However, she also underscores the borderlands of a more complex negotiation of belonging and identity (Pertersen, 2017) and revisits her positioning as an artist in the United States.

Liza Gobler places her artworks at the centre of her efforts to create social change. She has a self-interrogative démarche in expressing a form of activism, which fits more neoliberalist discourses in understanding the world "with particular kinds of inducements" (Kennelly, 2014, p. 243). In finding an individualised agency, her artworks link from inner to the outer landscapes as well as from the real to the imaginary, yet with a unique way of thinking and collaborating with others, while her approach resonates to what Hanna Arendt refers to as the human capacity for action (Arendt \& Canovan, 1998). Liza Gobler's artworks provide the "'space of appearances' and 'web of relations' as useful tools for re-imagining how activism" (Kennelly, 2014, p. 244) through art, plays an important role within democratic public spheres and how women artists might continue such engagements within diverse social movements. Tracy Dods' artworks underline a strong political and economic rhetoric and she equally displays the ambivalences and activism in giving support to democratic ideals for her country. In her work, ideas of resistance are rerouted through discussions of agency, away from matters of individuation buttowards issues about "power and the underlying conditions of possibility for different modalities of action"(McNay, 2016, pp. 43-44). Women artists use "agency as resistance to endorse a processual notion of emancipation" in looking for particular ways of "inhabiting social structures to create oppositional spaces and pathways towards their empowerment (McNay, 2016, p. 45). However, this study also underlines how women artists can use their art practice to give them a non-prescriptive pathway to express their ideas and views and less as a blueprint for their emancipation.

\section{Subjectivities from differing ideologies and philosophies - Influencing art practices}

Performative metaphors extend an understanding of the women artist's individual subjectivities with differing ideologies, philosophies that surround and influence their ideas, and art practice. Their artworks draw attention to the different ways they enact and represent their beliefs, which also extend to discursive meanings and messages. In the same vein, their views articulate collective subjectivities with ideas and practices providing them more "openended and experimental forms of politicised ethics" (McNay, 2016, p. 45). Dana Awartani and Alicia Marvan for instance, interrogate the normative limits in defining cultural and religious identities as they attempt to acknowledge or go beyond them. Blocker (1999) suggests 'performativity' can sometimes undermine the easy location of identity and the coherence of categories like the personal and political or the religious part of the self. In other words, viewing their acts as inseparable from complex discursive power relations, there is more to what binds their art practices and these include factors such as nationalism, cultural identity, gender, or even exile from a hybrid status as in Alicia Marvan's case. Alicia Marvan, Liza Gobler, and Tracy Dods all show concerns and efforts in challenging issues influencing their art practice (Herrero, 2012). Sometimes they even transgress power boundaries, whereas Dana Awartani is more subtle in affirming her views and positions, although she practices from SaudiArabia.

\section{Geographic positioning influencing the visibility of women artists}

The four women artists refer to the diverse opportunities and avenues regarding their artistic practice being in different parts of the world. Dana Awartani and Liza Gobler found their geographical positioning to offer them various opportunities in developing their ideas, art skills, as well as their values and beliefs in preserving the authenticity of traditional forms of art (Islamic art and South African art). Liza Gobler also finds her creative output and inspiration in her current environment to enact her values and beliefs towards a positive contribution for awareness on world issues as she explores ideas and possibilities towards a resolution through her artworks. Tracy Dods highlights her family background, upbringing and current living experiences in the Blue Mountains to have inspired and empowered her becoming in an artist and in adopting the political rhetoric, she explores in her artworks. Douglas and Fremantle (2006) affirm, "artists are increasingly interested in creating the conditions in which their challenges, desires, and tensions of changing social, environmental and cultural circumstances become exposed and revealed" (p.1). Alicia Marvan, Liza Gobler, and Tracy Dods indicate their roles as subversive leaders in representing their ideas and intentions in their artworks in the public discourse (Douglas \& Fremantle, 2006). Although they practice 
from different geographic locations considered core, semi-peripheral,andperipheral countries, they position themselves opportunistically (Erenrich \& Wergin, 2017) in demonstrating their agency and voice.

\section{Conclusion}

It is worth noting that the women artists' views and their artworks played a key role in the structuring of this paper. The researcher's reflexive engagement as an artist allowed the reciprocity in acknowledging the women artists' perspectives. A reflexive dialogue was useful in exploring the participant's individual views; however, it also created opportunities to understand their challenges and other collective subjectivities. For instance, the shifting hybrid subject position of Alicia Marvan as a migrant artist provided a unique lens in exploring her subjectivities and artistic representations towards activism, agency, and voice. All four women artists' underscored, in their responses, how they are constituted by and constitutive of their social, cultural, religious, and geographical positioning and how these factors validate or challenge their responses. The boundaries of nationality, socio-cultural and religious identity, and gender foreground some unquestioned value systems termed as 'performative metaphors' and subjectivities that address various issues influencing the women artists' views and art practice. The women artists' views and artworks are individually inspiring, yet, collectively their perspectives extend further understanding onto a multiplicity of issues and factors, which give meaning and purpose to their ideas and artistic representations. Art practice is discussed more like a transitory site affording the women artists a space to negotiate their identities, values, and beliefs as well as agency and voice. Although this study brings the 'voice' of only four women artists to the fore, it creates new possibilities for other women artists to bridge collective identities as they might resonate to similar views and experiences. The performative nature of the four women artists (Phillips et al., 2013) thus, direct cartographies to bridge 'nomadic connections' and collective identities (Tamboukou, 2010b; Zamorano Llena, 2004). Extending their views to a broader audience creates an avenue to trigger other conversations on the subjectivities and issues that influence other women artists' art practice and visibility (Madison, 2011).

Research under-theorises the visibility of other women artists from global peripheral countries and those with a migrant artist identity (Bal \& Hernández-Navarro, 2011; Dekel, 2016; Pertersen, 2017). This paper contributes to an understanding of some of the sociocultural implications and subjectivities influencing women artists having different profiles and practicing in various parts of the world. In acknowledging the views these women artists, this paper contributes to the global discourse on art and it helps to challenge and demystify some of the stereotypical thinking vis à viswomen artists in regards to their positioning and art practice. Although this paper does not focus primarily on the gender influence in the art world, it brings a salient discussion about women artists. Geographical positioning often can impair or empower women artists' motivation and visibility, while also dictating the value assigned their works based on the normative modern art canons. The issues of women artists practicing from the global peripheries and those negotiating a migrant artist identity (Petersen, 2017) is often overlooked, hence their voices often remain less heard. As global mobility increases the movement of artists (Petersen, 2017), this situation provokes rethinking on a myriad of issues that contribute to global art practices (Iskin, 2017; Petersen, 2017). The revisiting of issues around no madism, mobility, and the precarious conditions and livelihoods of artists (Adey, 2017 ) thus needs further research. This paper provides an empirical direction to research on women artists, however, it builds an understanding on their art practice and opens an important discussion in exploring 'performative metaphors' and subjectivities influencing their views and visibility while triggering a much needed and ongoing conversation in this field. 


\section{Appendix 1}

\section{Questionnaire}

1. Please give a brief overview of your artistic profile, including any other involvement in Art Education - (e.g. as an artist in residence or in art workshops)

2. Briefly, describe your work and the process of creating your artworks. You can comment on your studio space, genre and artwork style and the mediums you work with.

3. Please choose two or three of your artworks and describe what they represent? You can describe the conceptual framework or any influences or messages and meanings conveyed through them (Please attach photos of these works with captions )

4. How would you define your ethnicity, gender, and cultural identity to influence your ideas, thoughts and what you represent as messages and meanings through your artworks?

5. How does any of your artworks represent issues related to your identity or hybridity of multiple or multi-layered identities?

6. How would you assess your positioning within a particular space, place, or geographic location to influence your opportunities, inspirations, and perceptions in your art practice?

7. Do any of these factors - economic, political, social and cultural background, changes in the socio-economic where you currently live and practice influence your ideas, identity, and what you represent in your artworks?

8. Are there any other ideologies, influences or connections, or any subjectivities that influence your artistic practice? If so, how these are represented as themes or messages in your artworks?

9. In your opinion, to your view shifts in how you designate creativity, expression, and representation in your artworks as challenged and influenced by the social, cultural, political, and economic transient global conditions?

\section{References}

Adey, P. (2017). Mobility. New York: Routledge.

Ahmed, S. (2003). Uprootings/regroundings: questions of home and migration ( $1^{\text {st }}$ ed.) New York: Oxford

Al-Dosari, H. (2016). Saudi male-guardianship laws treat women as second-class citizens. The Guardian. Retreived 7 October 2016.

Arendt, H., \& Canovan, M. (1998). The human condition: ( $2^{\text {nd }}$ ed.) Chicago: University of Chicago Press.

Armstrong, C. M., \& de Zegher, C. (2006). Women artists at the millennium. Cambridge, MA: MIT Press.

Bal, M., \& Hernández-Navarro, M. Á. (2011). Art and visibility in migratory culture : Conflict, resistance, and agency. Leiden, Netherlands: Brill.

Berman, K. (2017). Finding Voice: A visual arts approach to engaging social change. United States: University of Michigan Press.

Bettez, S.C. (2015). Navigating the complexity of qualitative research in postmodern contexts: assemblage, critical reflexivity, and communion as guides. International Journal of Qualitative Studies in Education, 28(8), 932-954.

Blocker, J. (1999). Where is Ana Mendieta? : Identity, performativity, and exile. Durham, NC: Duke University Press.

Bradley, M. (2015). Performing hybrid identities, Corporeal style. An exploration of three Feminist Latin American performance artists. Revista de Lenguas Modernas, 25, 369-380.

Butler, J. (1990). Gender trouble : feminism and the subversion of identity. New York: Routledge.

Butler, J. (1996). Performative acts and gender constitution. In M. Huxley \& N. Witts (Eds.), The twentiethcentury performance reader. London: Routledge.

Butler-Kisber, L. (2010). Qualitative inquiry: thematic, narrative and arts-informed perspectives. Los Angeles, London: SAGE.

Carspecken, P. F. (1996). Critical ethnography in educational research: A theoretical and practical guide. New York, London: Routledge. 
Carspecken, F. P. (2013). Critical ethnography in educational research: A theoretical and practical guide. New York, London: Routledge.

Chase-Dunn, C., Kawano, Y., \& Brewer, B. D. (2000). Trade globalization since 1795: Waves of integration in the world-system. American Sociological Review, 65(1), 77-95. doi:10.2307/2657290

Cohen, L. (2018). Research methods in education ( $8^{\text {th }}$ ed.): Abingdon, Oxon, New York, NY: Routledge.

Creswell, J. W. (2007). Qualitative inquiry and research design: Choosing among five approaches.(2nd ed.) Thousand Oaks, London, New Delhi: SAGE Publications.

Creswell, J. W. (2012). Qualitative inquiry and research design: Choosing among five approaches. (3rded.) Singapore: SAGE Publications.

Deepwell, K. (1998). Women artists and modernism. New York: Manchester University Press.

Dekel, T. (2016). Transnational identities: Women, art, and migration in contemporary Israel: . Detroit, Michigan: Wayne State University Press.

Douglas, A., \& Fremantle, C. (2006). When is the artist a creative leader? A provisional network. Paper presented at the Proceedings of the creative rural economy conference, Rams bottom, Littoral.

Elkins, J., Valiavicharska, Z., \& Kim, A. (2010). Art and globalization. Unity Park, Pennsylvania: Pennsylvania State University Press.

Ellsworth, E. (1992). Why Doesn't this Feel Empowering? Working throug the repressive myths of critical pedagogy. In C. Luke \& J. Gore (Eds.), Feminisms and critical pedagogy (pp. 90-119). New York: Routledge.

Erenrich, S. J., \& Wergin, J. F. (2017). Grassroots leadership and the arts for social change. UK: Emerald Publishing Limited.

Felluga, D. F. (2015). Critical theory: The key concepts. New York: Routledge.

Fernandez, J. W. (1972). Persuasions and performances: Of the beast in every body... and the metaphors of everyman. Daedalus, 101(1), 39-60.

Fernandez, J. W. (1977). The performance of ritual metaphors. In J. Sapir \& J. C. Crocker (Eds.), The social use of metaphor: Essays on the anthropology of rhetoric. Philadelphia: University of Philadelphia Press.

Fernandez, J. W. (1986). Persuasions and performances: The play of tropes in culture. Blomington: Indiana University Press.

Fortnum, R. (1998). What issues are important for the upcoming generation of women artists? MAKE Magazine (81), 22.

Gillham, B. (2008). Developing a questionnaire $\left(2^{\text {nd }}\right.$ ed.). London: Continuum International Publishing Group.

Gotsi, C.-G. (2005). Towards the formation of a professional identity: Women artists in Greece at the beginning of the twentieth century. Women's History Review, 14(2), 285-300.

Gray, S. (2009). The dictionary of British women artists. Cambridge: Lutterworth Press.

Grosenick, U., \& Becker, I. (2001). Women artists in the $20^{\text {th }}$ and $21^{\text {st }}$ Century. Köln ; Los Angeles: Taschen.

Harris, J. (2002). The new art history: A critical introduction. New York: Routledge.

Heartney, E., Posner, H., Princenthal, N., \& Scott, S. (2014). The reckoning: Women artists of the new millennium: Prestel Verlag.

Herrero, M. (2012). Review essay: Maria Tamboukou, In the fold between power and desire: Women artists' narratives and Maria Tamboukou, nomadic narratives, visual forces: Gwen John's letters and paintings. Qualitative Research, 12(5), 591-594. doi:10.1177/1468794112442303

Iskin, R. E. (2017). Re-envisioning the contemporary art canon: Perspectives in a global world. New York: Routledge.

Johnson, B., \& Christensen, L. (2010). Educational research: Quantitative, qualitative, and mixed approaches. Thousand Oaks, California: Sage Publications.

Jones, K., Runco, M. A., Dorman, C., \& Freeland, D. C. (1997). Influential factors in artist's lives and themes in their artwork. Creativity Research Journal, 10(2-3), 221-228. doi:10.1080/10400419. 1997.9651221

Guibernau, M., \& Rex, J. (2010). The ethnicity reader: Nationalism, multiculturalism and migration. UK: Polity.

Kennelly, J. (2014). 'It's this pain in my heart that won't let me stop': Gendered affect, webs of relations, and young women's activism. Feminist Theory, 15(3), 241-260. doi:10.1177/1464700114544611

Khakbaz, M. (2015). Feminism and identity in the work of contemporary Iranian female artists. (Masters of Research (Arts)), Queensland University of Technology, Brisbane, Australia. Retrieved from: https://eprints.qut.edu.au/91313/4/Mozhdeh\%20Khakbaz\%20Joybargholi\%20Thesis.pdf 
Kramarae, C., \& Spender, D. (2004). Routledge international encyclopedia of women: Global women's issues and knowledge. New York: Routledge.

Lather, P. (2008). Against empathy, voice and authenticity. In A. Y. Jackson \& L. A. Mazzei (Eds.), Voice in qualitative inquiry: Challenging conventional, interpretive, and critical conceptions in qualitative research (pp. 16-25). New York: Routledge.

Le Compte, M. D., \& Schensul, J. J. (2010). Designing and conducting ethnographic research: An introduction. Plymouth, UK: Alta Mira Press.

Madison, D. S. (2011). Critical ethnography: Method, ethics, and performance. Thousand Oaks, California: Sage Publications.

Mackinlay, E. (2007). Disturbances and dislocations: Understanding teaching and learning experiences in indigenous Australian women's music and dance. Germany: Peter Lang.

Magnus, K. D. (2006). The unaccountable subject: Judith Butler and the social conditions of intersubjective agency. Hypatia, 21(2), 81-103.

McNay, L. (2016). Agency. In L. J. Disch \& M. E. Hawkesworth (Eds.), The Oxford Handbook of Feminist Theory (pp. 39-60). New York: Oxford University Press.

Melucci, A. (1995). The process of collective identity. Philadelphia: Temple University Press

Mikaelsson, L. (2016). Religion. In L. J. Disch \& M. E. Hawkesworth (Eds.), The Oxford Handbook of Feminist Theory. New York: Oxford University Press.

Mirza, H. S. (2006). 'Race,' gender and educational desire. Race Ethnicity and Education, 9(2), 137-158. doi:10.1080/13613320600696623

O'Neill, M. (2001). Prostitution and feminism: towards a politics of feeling. Malden, Mass : Polity Press.

Ortony, A. (1975). Why metaphors are necessary and not just nice. Educational Theory, 25(1), 45-53. doi:10.1111/j.1741-5446.1975.tb00666.x

Petersen, A. R. (2017). Migration into art : transcultural identities and art-making in a globalised world: Manchester: Manchester University Press

Phillips, L., Kristiansen, M., Vehviläinen, M., \& Gunnarsson, E. (2013). Tackling the tensions of dialogue and participation - Reflexive strategies for collaborative research. In L. Phillips, M. Kristiansen, M. Vehviläinen, \& E. Gunnarsson (Eds.), Knowledge and power in collaborative research: A reflexive approach UK: Routledge

Pink, S. (2001). Doing visual ethnography: images, media, and representation in research. London: Thousand Oaks, Calif: Sage.

Pink, S. (2013). Doing visual ethnography (3rd edition. ed.). Thousand Oaks, California: Sage Publications.

Pollock, G. (2013). How much does gender influence the art world? Retrieved from: https://www.telegraph.co.uk/women/womens-life/10184705/How-much-does-gender-influence-the-artworld.html

Riggins, S. H. (1994). The socialness of things: essays on the socio-semiotics of objects. Berlin New York: Berlin New York: Mouton de Gruyter.

Saldana, J. (2011). Fundamentals of qualitative research. UK: Oxford University Press

Simon, R. I., \& Dippo, D. (1986). On critical ethnographic work. Anthropology \& Education Quarterly, 17(4), 195-202.

Stanczak, G. C. (Ed.) (2007). Visual research methods, image, society, and representation. London: Sage Publications.

Subreenduth, S., \& Jeong-eun, R. (2010). A porous, morphing, and circulatory mode of self-other: decolonizing identity politics by engaging transnational reflexivity. International Journal of Qualitative Studies in Education (QSE), 23(3), 331-346. doi:10.1080/09518390903156215

Tamboukou, M. (2010a). In the fold between power and desire: Women artists' narratives. UK: Cambridge Scholars Publisher.

Tamboukou, M. (2010b). Nomadic narratives, visual forces: Gwen John's letters and paintings. New York: Peter Lang.

Thomas, J. (1993). Doing critical ethnography. Newbury Park, California: Sage Publications.

Thomas, J., \& O' Maolchatha, A. (1989). Reassessing the critical metaphor: An optimistic revisionist view. Justice Quarterly, 6(2), 143-172. doi:10.1080/07418828900090111

Trent, A., \& Cho, J. (2014). Interpretation strategies: Appropriate concepts. In P. Leavy (Ed.), The Oxford Handbook of Qualitative Research. Oxford New York: Oxford University Press.

Wolcott, H. F. (1999). Ethnography: A way of seeing. Lanham, New York: Altamira Press.

Wolcott, H. F. (2008). Ethnography: A way of seeing (2nd ed.). Lanham, MD: Lanham, MD: Altamira Press. 
Wolff, J. (1981). The social production of art (pp. 26-48). London: Macmillan Education UK.

Zamorano Llena, C. (2004). The salvage from postmodernism: Nomadic subjectivity in contemporary women's poetry in the British Isles. E-rea [Online], 2.2 | 2004, 2.2. Retrieved from: http://erea.revues.org /444 doi: 10.4000 / erea.444

Zembylas, M. (2005). Teaching with emotion : A postmodern enactment. Greenwich, CT : Information Age Pub. 